\title{
Gadolinium contrast agents: over exposure?
}

\author{
Robert W Biederman*, Ronald B Williams, Mark Doyle, June A Yamrozik, Moneal Shah, Geetha Rayarao, \\ Sirikarn Napan \\ From 19th Annual SCMR Scientific Sessions \\ Los Angeles, CA, USA. 27-30 January 2016
}

\section{Background}

MRI has dramatically changed the way we diagnose disease. With the introduction of contrast agents specifically for MRI, we were now able to see that which was 'invisible'. Gadopentetate dimeglumine (Magnevist ${ }^{\circledR}$ ) was introduced over 20 years ago, since then many more agents with variable features have been introduced. Several newer agents have improved 'relaxivity' and some designated for organ specify use. Along with the increased administration of these agents, has been the emergence of an associated disease complex, Nephrogenic Systemic Fibrosis (NSF). This is an issue only in severely impaired renal function patients $(\mathrm{eGFR}<30 \mathrm{~mL} /$ $\min / 1.73 \mathrm{~m}^{2}$ ). With increased understanding, the incidence of NSF has plummeted. Some agents such as MultiHance ${ }^{\circledR}$ (gadobenate dimeglumine) have never had a single episode of NSF. Most recently a 'new' issue with gadolinium-based contrast agents has emerged; intracranial gadolinium deposition appearing presumably late only after multiple contrast MRI's. McDonald and Radbruch, noted gadolinium in pts' brain tissue especially in the globus pallidus, thalamus, dentate nucleus and pons in pts with at least four contrast exams. More troubling, as opposed to NSF, this finding was found in pts with preserved GFR $\left(\right.$ eGFR $\left.\geq 49 \mathrm{~mL} / \mathrm{min} / 1.73 \mathrm{~m}^{2}\right)$.

\section{Objective}

To perform a real-world temporal analysis of the frequency in which $>4$ cumulative doses of gadolinium was administered.

\section{Methods}

We performed a retrospective examination of our CMR studies to assess the usage of gadolinium (MultiHance) and frequency of exposure to multiple doses normalized by weight. In all cases, we used a weight based dosing formula. Accordingly, we have the following clinical examples for doses showing various administrations: Doseage $=(\mathrm{Kg})(0.1 / \mathrm{Kg})(1 \mathrm{ml} / 0.5 \mathrm{mmol})$ or simply: Doseage $=(\mathbf{K g})(0.2 \mathrm{ml})$ for a single dose. Figure 1.

\section{Results}

For 2000 patients given MultiHance (2010-2015), Figure 1 shows the range of gadolinium exposures,

\begin{tabular}{|c|c|c|c|c|}
\hline Weight (Kg) & Half Dose & Single Dose & Cardiac study & $\begin{array}{c}\text { Double Dose (Liver } \\
\text { Tranplant Study*) }\end{array}$ \\
\hline 50 & 5 & 10 & 15 & 20 \\
\hline 100 & 10 & 20 & 30 & 40 \\
\hline 150 & 15 & 30 & 45 & 60 \\
\hline *Liver transplant studies are done as Rest, Stress, and dyna mic Liver sequences included in exam. \\
\hline
\end{tabular}
Figure 1

Cardiac MRI, Allegheny General Hospital, Pittsburgh, PA, USA

() Biomed Central

(c) 2016 Biederman et al. This is an Open Access article distributed under the terms of the Creative Commons Attribution License (http://creativecommons.org/licenses/by/4.0), which permits unrestricted use, distribution, and reproduction in any medium, provided the original work is properly cited. The Creative Commons Public Domain Dedication waiver (http://creativecommons.org/ publicdomain/zero/1.0/) applies to the data made available in this article, unless otherwise stated. 


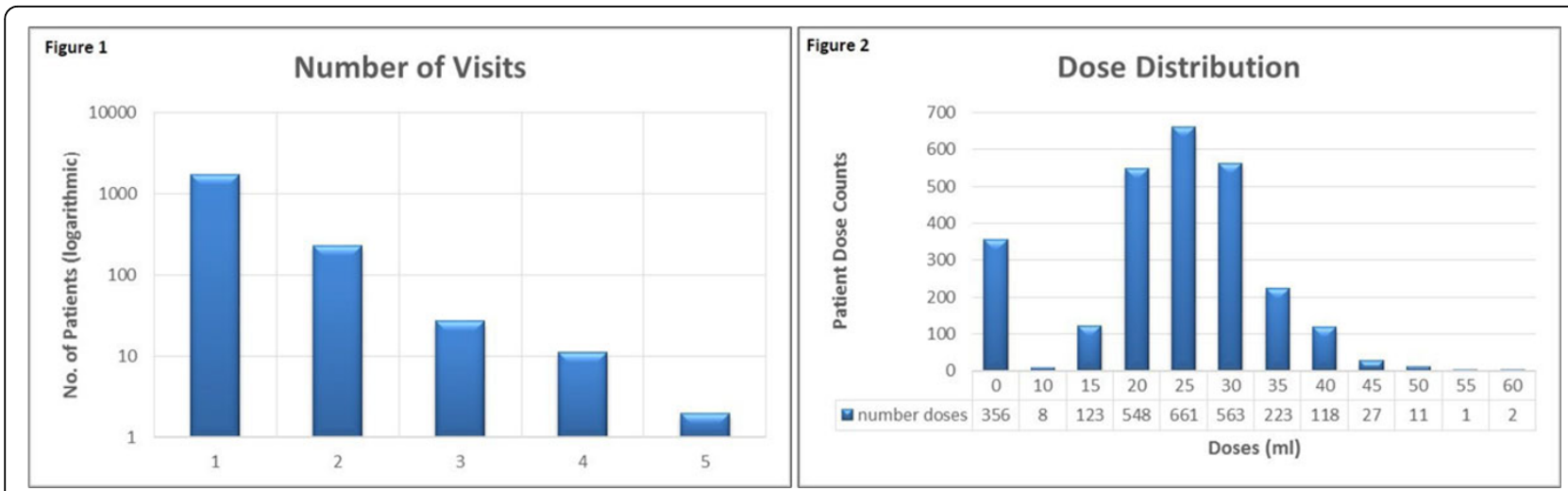

Figure 2

revealing a non-Gaussian distribution. In Figure 2, we show a near-Gaussian distribution of dose amounts, peaking at $25 \mathrm{ml}$.

\section{Discussion}

In our experience, only a small percentage of pts received multiple doses of gadolinium, with $\geq 4$ exposures representing only $0.65 \%(13 / 1982)$ of the sampled population. Assuming similar practice patterns as our high-referral CMR center, the $100^{+}$million doses world-wide pts exposed to gadolinium each year, we suggest that a similar percentage, $0.65 \%$, would receive multiple exposures $(>4)$, and they represent a sufficiently small population that could be followed on a society-wide initiative to better understand brain deposition significance.

\section{Conclusions}

Given the available information in this newly 'discovered entity' and assuming this has clinical relevance, until a 'better' MRI agent can be found, gadolinium agents still remain the best modality for optimizing clinical diagnoses for MRI sequences. This is especially evident in CMR where infiltrative diseases, MI's and other cardiomyopathies are optimized utilizing these contrast agents.
doi:10.1186/1532-429X-18-S1-T7

Cite this article as: Biederman et al:: Gadolinium contrast agents: over exposure?. Journal of Cardiovascular Magnetic Resonance 2016 18(Suppl 1): T7.
Submit your next manuscript to BioMed Central and take full advantage of:

- Convenient online submission

- Thorough peer review

- No space constraints or color figure charges

- Immediate publication on acceptance

- Inclusion in PubMed, CAS, Scopus and Google Scholar

- Research which is freely available for redistribution

Submit your manuscript at www.biomedcentral.com/submit
C Biomed Central 